\title{
THE LAND USE PRIORITY RANKING WITH THE APPROACH OF ANALYTIC HIERARCHY PROCESS (AHP) ON THE BOUNDARY OF ENTIKONG
}

\author{
Robby Irsan ${ }^{1 *}$, Luthfi Muta'ali ${ }^{2}$, Sudrajat $^{3}$ \\ ${ }^{1}$ Doctoral Program of Environmental Science, Gadjah Mada University, Indonesia \\ ${ }^{2,3}$ Faculty of Geography, Gadjah Mada University, Indonesia \\ ${ }^{*}$ Corresponding Author (e-mail: beetreecyber110683@gmail.com)
}

Received: 21 July 2018/Revised: 7 August 2018/Accepted: 16 August 2018/Published online: 28 August 2018

\begin{abstract}
Entikong is a sub-districts located in the borderline, northern end of Sanggau Regency directly adjacent to Sarawak, Malaysia. The growth of Entikong as a center of growth does not provide a downward trickle effect, but it creates an excessive resources exploitation effect to the surrounding area (backwash effect). The land use within an area should be adjusted to its function. For that reason, this research will determine the priority and rank of land use by using the Analytic Hierarchy Process (AHP). The ranking is based on four aspects of criteria; social, economic, institutional, and environmental. The hierarchy model is sorted into alternatives, criteria, and sub-criteria. The criteria and subcriteriaare compared, as well as the value of consistency. After data processing and analyzing with Expert Choice software version 11, the researcher found that the main priority of land use in Entikong is for plantation, which is $29,7 \%$.
\end{abstract}

Keywords: AHP, Land Use, Expert Choice

\section{Introduction}

Entikong is one of the areas located in the borderline, northern end of Sanggau Regency, directly adjacent to Sarawak, Malaysia. EntikongSubdistrict has an area of 506, 89 $\mathrm{km} 2$, consisting of 5 villages and 28 hamlets, with a population of $\pm 13,514$ inhabitants (in 2012). Most of the residents of Entikong are farmers. The average population growth rate in Entikong is $9.51 \%$ per year. There is a heterogeneous ethnic assimilation of the community: Dayak, Malay, Javanese, Chinese, Banjar, and Bugis.

The growth of Entikong sub-district as a center of advancement does not provide a downward trickle effect, but it creates the depletion of resource effect of the surrounding area (backwash effect). This will cause the border areas to grow rapidly, while rural areas experience excessive resource depletion. Ernan Rustiadi and Sunsus Saefulhakim (2011) state that the occurrence of backwash effects can be caused by: (1). The opening of access to rural areas often encourages urban elites, government officials and large corporations to exploit the village's resources, while villagers themselves are powerless because of their political and 
economic power. In this case, resource exploitation actors have a much stronger bargaining position. 2). the rural areas are generally inhabited by the less developed and less institutionalized human resources, which results in the difficulty of accepting modern ideas in rural communities (3). inter-regional relationships have mutually weakened one another, where rural areas (hinterlands) are become the target of excessive resource depletion, while the growth is also slowing due to the tremendous urbanization process.

There are six factors that influence the process of land use change; (1) the physical characteristics of the land which is related to the physical condition of the land, such as land topography, fertility, irrigation, and so forth; (2) regulations concerning land use that is related to the designation of the land in accordance with existing regulations; (3) the personal characteristics of the landowner that is related to the socio-economic condition of the landowner; (4) the number of available public utilities. The complete public facilities will further encourage land use change; (5) the degree of accessibility of the land, which is related to affordability or accessibility in and from other places, and (6) the initiative of the builders, related to the chosen area used as the location of the construction of a large housing cluster (IPCC, 2000).

Changes in land use will continue to occur as population increases. Fandelli (2014) states that the continued increase of population, especially in developing countries, can cause some environmental problems such as: The urbanization process will cause air pollution, water, and soil problems; Population pressures on the land will be higher, so that the land will intensively result in erosion and sedimentation, while in some places there will be floods and landslides; Population pressures on forest areas can lead to declining biodiversity in forest ecosystems.

Land use management must be planned to have ecological, economic and social benefits to assure the sustainability of natural resources potential (Adimihardja, 2006). Land use planning should be adjusted to the spatial plan of a region. The intention is to avoid misapplication purpose of the development of a region. With good planning, the land use for agriculture, plantation, housing, and others can be maximized. The allocated land must be adapted to environmental conditions and consistent with the objectives of the regional development.

The natural, social, economic and cultural aspects of geography have been a major concern since they may form the spatial variation. In the spatialanalysis, the natural and human elements reside and interact dynamically to provide various visions. The appearance is a reflection of decision making in the utilization of the land and the outcome of the 
distribution of human activity in the past, present, and future. Meanwhile, the repetition of an object's appearance at a location is often referred to as spatial distribution. Distribution of objects or appearances that have similar characters in different locations is often called spatial patterns. In this dimension, the elements of distance, direction, and location are related (Giyarsih, 2010).

The proliferation of land used for plantations and housing in border areas makes the forest area limited. Based on the result of overlay analysis of land use map of Entikong Subdistrict in 2011 to 2017, the area of primary forest within the period of 6 years decreased by 7.018 Ha, while the plantation and settlement area increased by 3,637 Ha. This indicates that every year forest land decreases with the proliferation of plantations and settlements. This continues until recent days, although it is clear that it violates the function of forest resources as a counterweight to the environment.

AHP is a decision support model developed by Thomas L. Saaty. This support model describes the problem of multi-factor or complex multi-criteria into a hierarchy. According to (Saaty, 2008), the hierarchy is defined as a representation of a complex problem in a multilevel structure where the first level is the goal, followed by the factor level, criteria, subcriteria, and so on down to the last level of the alternative. Hierarchical or decision-making structures are undertaken to illustrate the identified system elements or decision alternatives.

Planning and utilization of appropriate allocation can optimize land use (Hidayat, Rustiadi, \& Kartodihardjo, 2015). Land use model will be optimal with functioning various criteria that can influence the land use (Prawira \& Ariastita, 2014). This study aims to obtain a priority ranking of land use from the aspects, criteria, sub-criteria, and alternative options for sustainable land use using AHP (Analytic Hierarchy Process) method based on the expert or key person views. The emphasis on my research is arranging an effective and operational land-spatial roadmap, as well as the decision of the priority sector with environmentally sound land use. This research will be different from previous research and from elsewhere, thus bring a novelty of this study.

\section{The Methods}

Basically, AHP is a general theory of measurement used to find the ratio scale of comparison. The AHP method is a framework for effective decisions making by simplifying and speeding up the decision-making process by solving a problem into parts. Followed by arranging the part or variable in a hierarchy arrangement, giving numerical value on subjective considerations about the importance of each variable so the dominant variable is 
consistent with the objectives of the study. After that sets which variable has the highest priority and acts to influence the outcome in that situation (Saaty, 2008).

The AHP method helps to solve complex problems by structuring a hierarchy of criteria and interested parties, by drawing considerations for developing weights or priorities. This method also combines the power of feelings and logic concerned with various issues. In addition, AHP also has special attention to deviations from consistency, measurement and dependence within and outside its structural elements. Consistency Ratio (CR) is the limit of inconsistency set by Saaty. Consistency Ratio is formulated as a comparison of consistency index (RI) (Saaty, 2008).

Key Informants are used to gaining information from stakeholders in order to compose the scenario of land use priority decision, which consists of 11 people. The number of samples supports in the decision system is 8-15 people (Bourgeois, Penunia, Bisht, \& Boruk, 2017). The key informational distribution includes local government, parliament, community leaders, and academics.

Table 1. Stakeholders Sampling Distribution Unit (Key Informants)

\begin{tabular}{clcc}
\hline No & \multicolumn{1}{c}{ Samples } & Amount & Information \\
\hline $\mathbf{1}$ & Local government & 4 & (1) BAPPEDA, (2) BPN, (3) Entikong Border Entity Management \\
& & 1 & Agency/UP3LB, (4) Entikong Sub-District Office \\
$\mathbf{2}$ & DPRD & 5 & Commission II for Economic Affairs and Development \\
$\mathbf{3}$ & Public figure & 1 & Village Head in Entikong Sub-District \\
$\mathbf{4}$ & Academics & 11 people & Land and Environmental Resources Expert \\
& Total & \\
\hline
\end{tabular}

The formulation of a decision-making model is implemented through the involvement of competent stakeholders in the field of border, land, environmental, and socio-economic management. Preparation of decision directives considers 6 (six) alternative decisions with priority development of agriculture, plantation, industry, mining, conservation, and tourism.

Table 2. Land Use Arrangement of Main Priority Area

\begin{tabular}{|c|c|c|c|}
\hline No & Variable & Criteria & Priority \\
\hline \multirow[t]{4}{*}{1} & Social & 1. Poverty & 1. Industry \\
\hline & & 2. People's Welfare & 2. Plantation \\
\hline & & 3. Quality of Education and Health & 3. Agriculture \\
\hline & & 4. Social Conflict & 4. Mining \\
\hline \multirow[t]{4}{*}{2} & Economy & 1. Employment Opportunities & 5. Tourism \\
\hline & & 2. Revenue & 6. Conservation \\
\hline & & 3. Regional Growth & \\
\hline & & 4. The pattern of Production and Consumption & \\
\hline \multirow[t]{4}{*}{3} & Institutional & 1. Connectivity within and between countries & \\
\hline & & 2. Local Institutions & \\
\hline & & 3. Interregional Trade Regulations & \\
\hline & & 4. Border Management & \\
\hline \multirow[t]{4}{*}{4} & Environment & 1. Environmental Conservation & \\
\hline & & 2. Environmental Supporting Capacity & \\
\hline & & 3. Environmental Degradation & \\
\hline & & 4. Sanitation Management & \\
\hline
\end{tabular}

Source :(Ishartono \& Raharjo, 2015) Sustainable Development Goals (SDGs) 
The next step is to create the hierarchical structure of the decision model in Table 2. Then do a pairwise comparison between each criterion and alternative, so the value of importance of each criterion and alternative in the form of the qualitative opinion is obtained. To quantify the qualitative opinion, the assessment scale is used to obtain an opinion value in the form of numbers (quantitative). The numerical values used for all comparisons are obtained on a scale of 1 to 3 as defined by (Saaty, 2008) with modifications, as showed in Table 3 below.

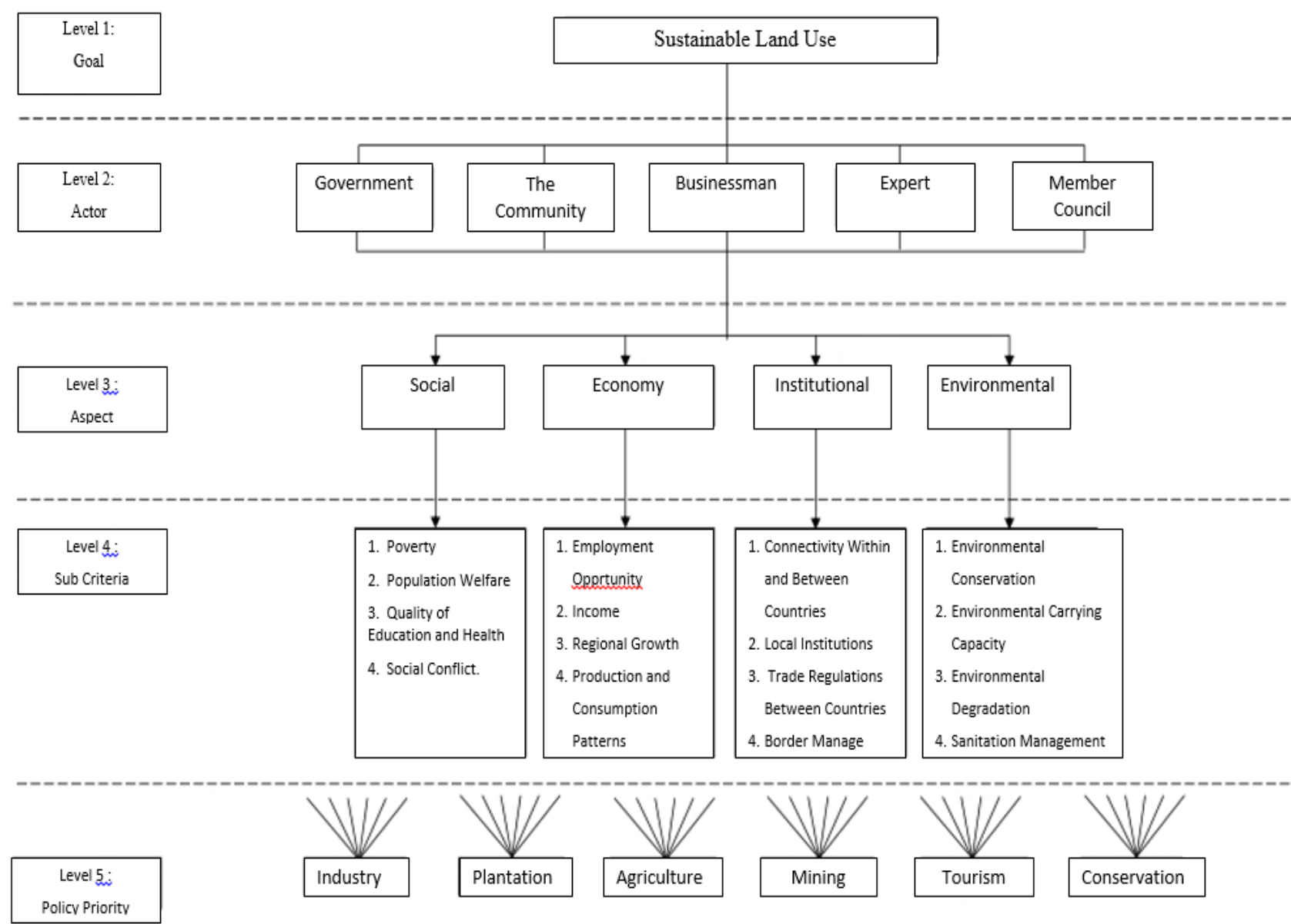

Figure 1. AHP Hierarchy Model of Sustainable Land Use

Table 3. Fundamental Comparison Scale

\begin{tabular}{|c|c|c|}
\hline Level of Interest & Definition & Elucidation \\
\hline 1 & $\begin{array}{l}\text { One element is slightly more } \\
\text { important than the other }\end{array}$ & $\begin{array}{l}\text { Experience and judgment strongly support an element } \\
\text { compared to other elements }\end{array}$ \\
\hline 2 & $\begin{array}{l}\text { One element is more important than } \\
\text { the other }\end{array}$ & $\begin{array}{l}\text { Experience and judgment strongly support an element } \\
\text { compared to other elements }\end{array}$ \\
\hline 3 & $\begin{array}{l}\text { One element is absolutely more } \\
\text { important than the other }\end{array}$ & $\begin{array}{l}\text { Evidence that supports one element against another has the } \\
\text { highest degree of affirmation that might be corroborating }\end{array}$ \\
\hline
\end{tabular}




\section{Results and Discussion}

Based on the decision aspect of land users, the value of consistency (0.07) is less than $10 \%$. This indicates that the value of the preferences can be used as a basis for conducting land use decision making in Entikong. The result of data processing by using Expert Choice software shows the priority value for criteria as shown in Table 4 and the result of calculating the priority value as shown in Figure 2.

Table 4. Priority Values for Criteria

\begin{tabular}{cccc}
\hline No & Criteria & Priority Score & Inconsistency \\
\hline 1 & Social & 0,220 & 0,07 \\
2 & Economy & 0,523 & \\
3 & Institutional & 0,103 & \\
4 & Environment & 0,153 & \\
\hline
\end{tabular}

Source: Analysis Results

Based on decision aspects of land users that covers social, economic, institutional and environmental criteria, the economic criteria has the highest value compared to other criteria. The result is shown by the score obtained on the economic criteria 0.523 , the next social criteria with a score of 0.220 , followed by environmental criteria 0.153 , and the last institutional criteria 0.103 .

The table above also shows an inconsistency value of 0.07 , the inconsistency value is less than $10 \%$ alpha $(0.07<0.10)$, which means that the economic criteria are the dominant criteria in the land user decision aspects, which have been consistent.

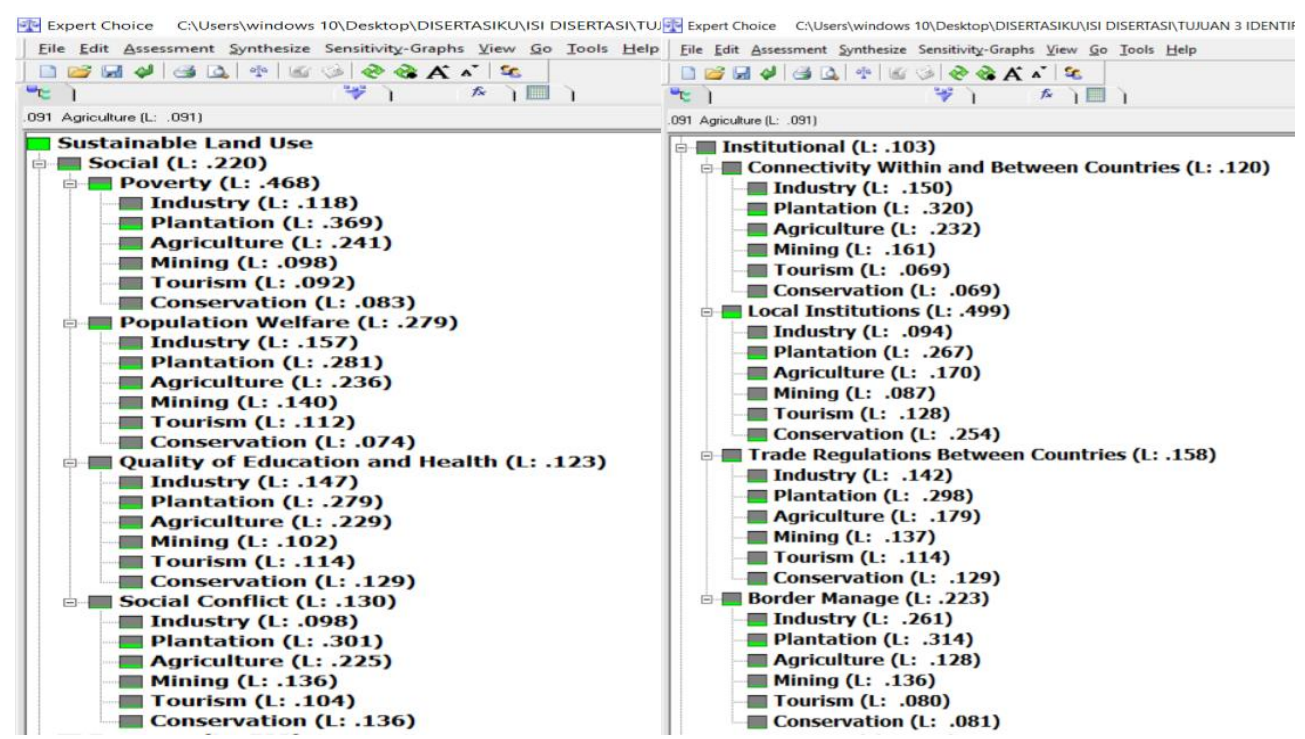




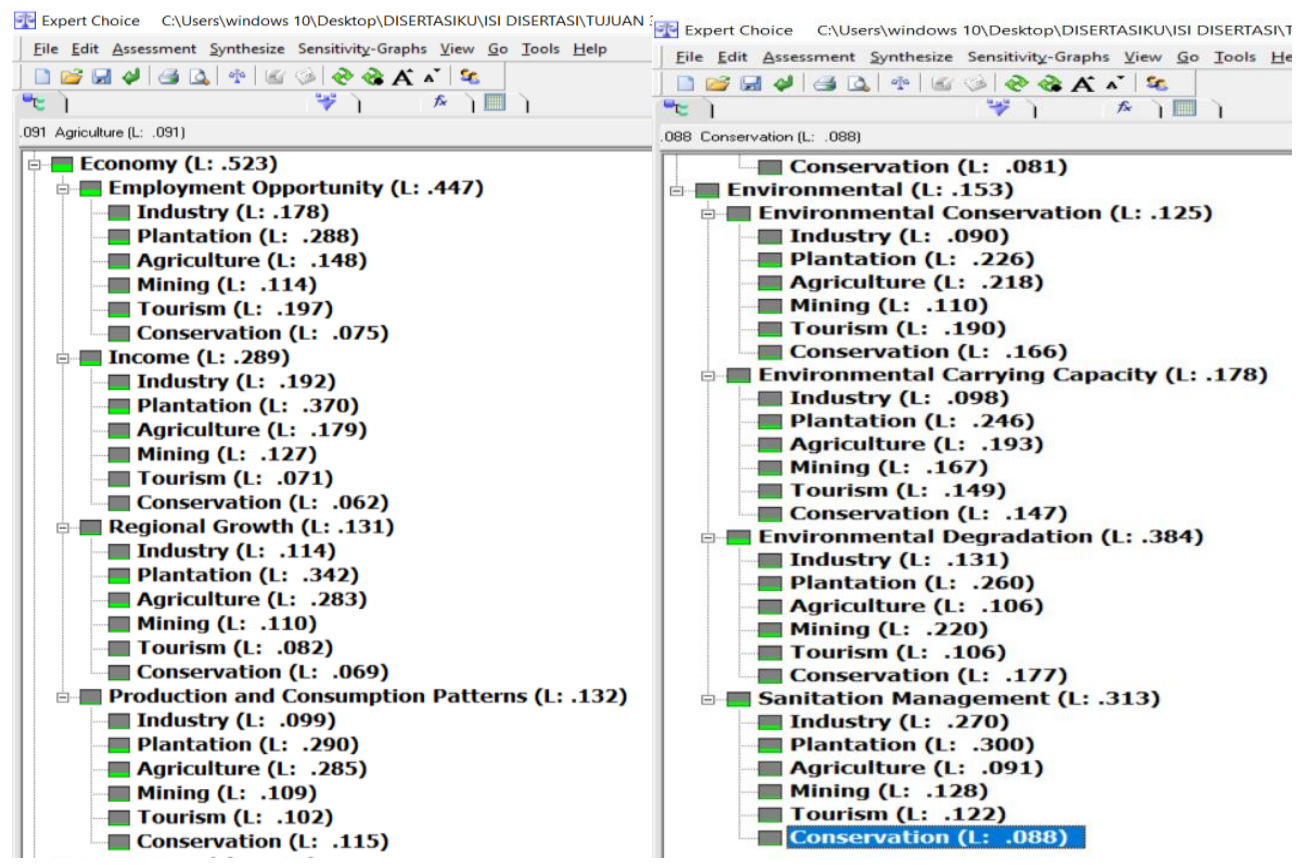

Figure 2. Calculation of Eigenvalues Results (Priority)

As a whole, the calculations shown in Figure 2 can be found in Table 5, and Table 6 below.

Table 5. Priority Values for Sub Criteria

\begin{tabular}{cclcc}
\hline No & \multicolumn{1}{c}{ Criteria } & \multicolumn{1}{c}{ Sub Criteria } & Score & Inconsistency \\
\hline 1 & Social & Poverty & 0,468 & 0,008 \\
& & People's Welfare & 0,279 & \\
& & Quality of Education and Health & 0,123 & \\
\multirow{2}{*}{2} & \multirow{2}{*}{ Economy } & Social Conflict & 0,130 & \multirow{2}{*}{0,09} \\
& & Employment Opportunities & 0,447 & \\
& & Revenue & 0,289 & \\
& & Regional Growth & 0,131 & \\
3 & \multirow{2}{*}{ Institutional } & The pattern of Production and Consumption & 0,132 & \multirow{2}{*}{0,09} \\
& & Connectivity within and between countries & 0,120 & \\
& & Local Institutions & 0,499 & \\
& & Interregional Trade Regulations & 0,158 & \\
& & Border Management & 0,223 & \multirow{2}{*}{ Environment } \\
& & Environmental Conservation & 0,125 & 0,07 \\
& & Environmental Supporting Capacity & 0,178 & \\
& & Environmental Degradation & 0,384 & \\
& & Sanitation Management & 0,313 & \\
\hline
\end{tabular}

Source: Analysis Results

Based on social criteria, poverty has the highest score compared to other sub-criteria. The inconsistency value shown in the social criterion is 0.008 , the value is less than $10 \%$ alpha $(0.008<0.10)$, means that the sub-dominant of the social sub-criteria, which is erasing poverty rates have been consistent. 
Based on the economic criteria, employment opportunity has the highest value compared to other sub-criteria. The inconsistency valueshown in the economic criteria is 0.09 , the value is less than $10 \%$ alpha $(0.09<0.10)$, means that the sub-dominant of the economic sub-criteria, which increases the employment opportunities, have been consistent.

Based on environmental criteria, environmental degradation have the highest value compared to other sub-criteria. The inconsistency valueshown in the environmental criteria is 0.07 , the value is less than $10 \%$ alpha $(0.07<0.10)$, which means that the sub-dominant of the environmental sub-criteria, which is the environmental degradation, has been consistent

Based on institutional criteria, local institution has the highest value compared to other sub-criteria. The inconsistency value shown in the institutional criteria is 0.09 , the value is less than $10 \%$ alpha $(0.09<0.10)$, which means that the sub-dominant of the institutional sub-criteria, which is the improvement of the local institutional role has been consistent.

Table 6. Land Use Priority Score

\begin{tabular}{|c|c|c|c|c|c|c|c|}
\hline No & Sub Criteria & Industry & Plantaction & Agriculture & Mining & Tourism & Conservation \\
\hline 1 & Poverty & 0.118 & 0.369 & 0.241 & 0.098 & 0.092 & 0.083 \\
\hline 2 & People's Welfare & 0.157 & 0.281 & 0.236 & 0.140 & 0.112 & 0.074 \\
\hline 3 & $\begin{array}{l}\text { Quality of Education } \\
\text { and Health }\end{array}$ & 0.147 & 0.279 & 0.229 & 0.102 & 0.114 & 0.129 \\
\hline 4 & Social Conflict & 0.098 & 0.301 & 0.225 & 0.136 & 0.104 & 0.136 \\
\hline 5 & $\begin{array}{l}\text { Employment } \\
\text { Opportunities }\end{array}$ & 0.178 & 0.288 & 0.148 & 0.114 & 0.197 & 0.075 \\
\hline 6 & Revenue & 0.192 & 0.370 & 0.179 & 0.127 & 0.071 & 0.062 \\
\hline 7 & Regional Growth & 0.114 & 0.342 & 0.283 & 0.110 & 0.082 & 0.069 \\
\hline 8 & $\begin{array}{l}\text { Pattern of Production } \\
\text { and Consumption }\end{array}$ & 0.099 & 0.290 & 0.285 & 0.109 & 0.102 & 0.115 \\
\hline 9 & $\begin{array}{l}\text { Connectivity within and } \\
\text { between countries }\end{array}$ & 0.150 & 0.320 & 0.232 & 0.161 & 0.069 & 0.069 \\
\hline 10 & Local Institutions & 0.094 & 0.267 & 0.170 & 0.087 & 0.128 & 0.254 \\
\hline 11 & $\begin{array}{l}\text { Interregional Trade } \\
\text { Regulations }\end{array}$ & 0.142 & 0.298 & 0.179 & 0.137 & 0.114 & 0.129 \\
\hline 12 & Border Management & 0.261 & 0.314 & 0.128 & 0.136 & 0.080 & 0.081 \\
\hline 13 & $\begin{array}{l}\text { Environmental } \\
\text { Conservation }\end{array}$ & 0.090 & 0.226 & 0.218 & 0.110 & 0.190 & 0.160 \\
\hline 14 & $\begin{array}{l}\text { Environmental } \\
\text { Supporting Capacity }\end{array}$ & 0.098 & 0.246 & 0.193 & 0.167 & 0.149 & 0.147 \\
\hline 15 & $\begin{array}{l}\text { Environmental } \\
\text { Degradation }\end{array}$ & 0.131 & 0.260 & 0.106 & 0.220 & 0.106 & 0.177 \\
\hline 16 & $\begin{array}{l}\text { Sanitation } \\
\text { Management }\end{array}$ & 0.270 & 0.300 & 0.091 & 0.128 & 0.122 & 0.088 \\
\hline & Average & 0.146 & 0.297 & 0.196 & 0.130 & 0.115 & 0.116 \\
\hline
\end{tabular}

Source: Analysis result 
Among priority land use, which includes industry, plantation, agriculture, mining, tourism, and conservation. The priority decision on the plantation is the dominant priority, indicated by the highest average grade score of priority compared with others. The average plantation priority score is 0.297 , followed by the agricultural priority with 0.196 , the industry priority with 0.146 , the mining priority with 0.130 , the conservation priority with 0.116 , and the tourism priority with 0.115 . Therefore it can be concluded that the most dominant priority in land use is a plantation.

\section{Conclusion}

From the calculation analysis the obtained results are:

a. Economic criteria are the most dominant criteria in land use decision making in Entikong.

b. The sub-dominant of the social sub-criteria, which is to eradicate poverty is an absolute thing to do.

c. The sub-dominant of the economic sub-criteria is to increase job opportunity.

d. The sub-dominant of the environmental sub-criteria is to erase environmental degradation.

e. The sub-dominant of the institutional sub-criteria is to increase the role of local institutions.

f. Among the priority decisions regarding land use which include industry, plantation, agriculture, mining, tourism, and conservation, decisions on plantation priority are the dominant priority

\section{Acknowledgments}

I am thanking Mr. Luthfi Muta'ali, and Dr. Sudrajat for providing willingness and time in research consultation, as well as prayer and support from his beloved wife Yulfitri and beloved son Ahsin Rifa in completing this research.

\section{References}

Adimihardja, A. (2006). Strategi mempertahankan multifungsi pertanian di indonesia. Jurnal Litbang Pertanian.

Bourgeois, R., Penunia, E., Bisht, S., \& Boruk, D. (2017). Foresight for all: Co-elaborative scenario building and empowerment. Technological Forecasting and Social Change. https://doi.org/10.1016/j.techfore.2017.04.018

Ernan Rustiadi, Sunsus Saefulhakim, D. R. P. (2011). Perencanaan dan Pengembangan Wilayah. Restpent Press. 
Fandelli, C. (2014). Bisnis Konservasi Pendekatan Baru Dalam Pengelolaan Sumberdaya Alam dan Lingkungan Hidup (2nd ed.). Yogyakarta: Gadjah Mada University Press. Retrieved from http://ugmpress.ugm.ac.id/id/product/sains-teknologi/bisnis-konservasipendekatan-baru-dalam-pengelolaan-sumberdaya-alam-dan-lingkungan-hidup

Giyarsih, S. R. (2010). POLA SPASIAL TRANSFORMASI WILAYAH DI KORIDOR YOGYAKARTA-SURAKARTA Spatial Pattern of Regional Transformation In Yogyakarta-Surakarta Corridor. Forum Geografi.

Hidayat, W., Rustiadi, E., \& Kartodihardjo, H. (2015). Dampak Pertambangan Terhadap Perubahan Penggunaan Lahan dan Kesesuaian Peruntukan Ruang (Studi Kasus Kabupaten Luwu Timur, Provinsi Sulawesi Selatan). Jurnal Perencanaan Wilayah Dan Kota. https://doi.org/10.5614/jpwk.2015.26.2.5

IPCC. (2000). Land Use, Land-Use Change, and Forestry. Forestry. https://doi.org/DOI: $10.2277 / 0521800838$

Ishartono \& Raharjo, S. T. (2015). Sustainable Development Goals (SDGs) Dan Pengentasan Kemiskinan. Social Work Jurnal. https://doi.org/ttps://doi.org/10.24198/share.v6i2.13198

Prawira, N. G. A., \& Ariastita, P. G. (2014). Rumusan Insentif dan Disinsentif Pengendalian Konversi Lahan Pertanian di Kabupaten Gianyar. Jurnal Teknik Pomits.

Saaty, T. L. (2008). Decision making with the analytic hierarchy process. International Journal of Services Sciences. https://doi.org/10.1504/IJSSCI.2008.017590 